\title{
Compartment-Specific Modulation of GABAergic Synaptic Transmission by TRPV1 Channels in the Dentate Gyrus
}

\author{
DAndrés E. Chávez, ${ }^{1}$ Vivian M. Hernández, ${ }^{2}$ Alma Rodenas-Ruano, ${ }^{1}$ C. Savio Chan, ${ }^{2}$ and Pablo E. Castillo ${ }^{1}$ \\ ${ }^{1}$ Dominick P. Purpura, Department of Neuroscience, Albert Einstein College of Medicine, Kennedy Center, Bronx, New York 10461 and ${ }^{2}$ Department of \\ Physiology, Feinberg School of Medicine, Northwestern University, Chicago, Illinois 60611
}

\begin{abstract}
The transient receptor potential TRPV1 or vanilloid receptor is a nonselective ligand-gated channel highly expressed in primary sensory neurons where it mediates nociception. TRPV1 is also expressed in the brain where its activation depresses excitatory synaptic transmission. Whether TRPV1 also regulates inhibitory synapses in the brain is unclear. Here, using a combination of pharmacology, electrophysiology, and an in vivo knockdown strategy, we report that TRPV1 activation by capsaicin or by the endocannabinoid anandamide depresses somatic, but not dendritic inhibitory transmission in both rat and mouse dentate gyrus. The effect on somatic inhibition was absent in TRPV1 knock-out mice and was also eliminated by two different TRPV1 shRNAs expressed in dentate granule cells, strongly supporting a functional role for TRPV1 in modulating GABAergic synaptic function. Moreover, TRPV1-mediated depression occurs independently of GABA release, requires postsynaptic $\mathrm{Ca}^{2+}$ rise and activation of calcineurin, and is likely due to clathrin-dependent internalization of GABA receptors. Altogether, these findings reveal a novel form of compartment-specific regulation whereby TRPV1 channels can modify synaptic function in the brain.
\end{abstract}

Key words: cannabinoid; endocytosis; feedforward inhibition; GABA; hippocampus; interneuron

\section{Introduction}

TRPV1, also known as VR-1 for vanilloid receptor type-1 (Caterina et al., 1997), is a nonselective, ligand-gated cation channel that can be activated by a variety of noxious, physical, and chemical stimuli, including endogenous lipid ligands such as the endocannabinoid (eCB) anandamide (AEA; Ross, 2003). These channels have been well characterized at afferent peripheral sensory neurons, where their activation regulates synaptic transmission associated with pain sensation (Caterina and Julius, 2001). Increasing anatomical, functional, and behavioral evidence supports the presence of functional TRPV1 channels also in the CNS (Sasamura et al., 1998; Mezey et al., 2000; Huang et al., 2002, 2014; Marinelli et al., 2003; D.P. Li et al., 2004; Roberts et al., 2004; Tóth et al., 2005; Cristino et al., 2006; Marsch et al., 2007; Gibson et al., 2008; H.B. Li et al., 2008; Maccarrone et al., 2008; Aguiar et al., 2009; Maione et al., 2009; Musella et al., 2009, 2010; Chávez et al., 2010; Grueter et al., 2010; Bennion et al., 2011; Puente et al., 2011, 2014; P. Han et al., 2013; Terzian et al., 2014). Of note, a recent report suggests that TRPV1 channels are re-

Received Aug. 31, 2014; revised 0ct. 13, 2014; accepted 0ct. 29, 2014.

Author contributions: A.E.C. and P.E.C. designed research; A.E.C. and A.R.-R. performed research; V.M.H. and C.S.C. designed and generated all shRNA vectors; A.E.C. and A.R.-R. analyzed data; A.E.C. and P.E.C. wrote the paper.

This work was supported by National Institutes of Health grants to P.E.C. (DA017392 and MH081935) and C.S.C. (NS069777 and NS069777-S1). A.E.C. was partially supported by a Ruth L. Kirschstein Award (F32 NS071821) and a National Alliance for Research on Schizophrenia and Depression Young Investigator Grant from the Brain \& Behavior Research Foundation. We thank Thomas Younts for critical reading of this manuscript.

The authors declare no competing financial interests.

Correspondence should be addressed to either Andrés E. Chávez or Pablo E. Castillo, Dominick P. Purpura Department of Neuroscience, Albert Einstein College of Medicine, 1410 Pelham Parkway South, Kennedy Center, Room 703, Bronx, NY 10461. E-mail: andres.chavez@einstein.yu.edu or pablo.castillo@einstein.yu.edu.

DOl:10.1523/JNEUROSCI.3635-14.2014

Copyright $\odot 2014$ the authors $\quad 0270-6474 / 14 / 3416621-09 \$ 15.00 / 0$ stricted to a few brain areas (Cavanaugh et al., 2011). Thus far, most work in the brain has focused on the role of TRPV1 channels at excitatory synapses where their activation can modify synaptic transmission via both presynaptic (Marinelli et al., 2002, 2003; Gibson et al., 2008; Musella et al., 2009; Köles et al., 2013) and postsynaptic mechanisms (Chávez et al., 2010; Grueter et al., 2010; Puente et al., 2011; Kim et al., 2012). However, the role of TRPV1 channels at inhibitory synapses remains poorly understood.

TRPV1 channels can indirectly modulate inhibition by regulating excitatory afferents onto GABAergic interneurons (Derbenev et al., 2006; Ferrini et al., 2007; Zhou et al., 2007; Gibson et al., 2008; Liao et al., 2011), or by mobilizing eCBs (Maccarrone et al., 2008) that suppress GABA release via type-1 cannabinoid receptors (CB1Rs). In the dentate gyrus (DG), a key relay station that controls information transfer from the entorhinal cortex into the hippocampus, inhibitory interneurons make somatic and dendritic synapses onto dentate granule cells (DGCs; Z.S. Han et al., 1993; Hefft and Jonas, 2005; Liu et al., 2014). GABA release from somatic inhibitory inputs onto DGCs can be modulated by presynaptic CB1Rs (Isokawa and Alger, 2005; Liu et al., 2014), and anatomical evidence suggests CB1R and TRPV1 colocalize in the DG (Cristino et al., 2006). It remains unknown whether TRPV1 directly regulates inhibitory transmission and whether CB1Rs act cooperatively to regulate GABAergic synapses in the DG.

Here we sought to determine the role of TRPV1 in GABAergic transmission. Using rat and mouse hippocampal slices, selective pharmacology, TRPV1 knock-out mice, and in vivo knockdown strategies, we report that TRPV1 activation selectively reduces somatic, but not dendritic inputs in a transmitter release- and 
CB1R-independent manner. This TRPV1-mediated depression of inhibitory synaptic transmission requires postsynaptic $\mathrm{Ca}^{2+}$ rise and calcineurin activation, and it is likely mediated by the internalization of type-A GABA receptors $\left(\mathrm{GABA}_{\mathrm{A}} \mathrm{R}\right)$. These results reveal an unexpected form of eCB-mediated regulation of GABAergic transmission along the somatodendritic axis of DGCs.

\section{Materials and Methods}

All procedures outlined in this study were approved by the Animal Care and Use Committee of Albert Einstein College of Medicine, in accordance with National Institutes of Health guidelines.

Hippocampal electrophysiology. Acute transverse hippocampal slices (400 $\mu \mathrm{m}$ thick), except for AAV-shRNA slices (290 $\mu \mathrm{m}$ thick), were prepared from Wistar or Sprague Dawley rats, postnatal P15-P32, and C57BL/6 mice (Trpv1 $1^{+/+} / \operatorname{Trpv1} 1^{-/-}$: P24-P33; cnr1 (CB1R) ${ }^{+/+} /$cnr1 (CB1R) $)^{-1-}$ : P27-P32), either sex, as previously described (Chávez et al., 2010; Rodenas-Ruano et al., 2012). Briefly, the hippocampi were isolated and cut in a solution containing the following (in $\mathrm{mM}$ ): 215 sucrose, 2.5 $\mathrm{KCl}, 26 \mathrm{NaHCO}_{3}, 1.6 \mathrm{NaH}_{2} \mathrm{PO}_{4}, 1 \mathrm{CaCl}_{2}, 4 \mathrm{MgCl}_{2}, 4 \mathrm{MgSO}_{4}$, and 20 glucose. Thirty minutes post sectioning, slices were incubated in extracellular ACSF recording solution containing the following (in $\mathrm{mM}$ ): $124 \mathrm{NaCl}, 2.5 \mathrm{KCl}, 26 \mathrm{NaHCO}_{3}, 1 \mathrm{NaH}_{2} \mathrm{PO}_{4}, 2.5 \mathrm{CaCl}_{2}, 1.3 \mathrm{MgSO}_{4}$, and 10 glucose. All solutions were equilibrated with $95 \% \mathrm{O}_{2}$ and $5 \%$ $\mathrm{CO}_{2}$, pH 7.4.

Hippocampal slices were visualized using infrared DIC and nontargeting GFP-control and Trpv1-shRNA DGCs were visualized using fluorescence video microscopy on a Nikon eclipse E600FN microscope (Fig. $2 A$ ). All experiments, except where indicated, were performed at $28 \pm$ $1^{\circ} \mathrm{C}$ in a submersion-type recording chamber perfused at $\sim 1-2 \mathrm{ml} / \mathrm{min}$ with ACSF supplemented with $10 \mu \mathrm{M}$ NBQX and $25 \mu \mathrm{M}$ D-APV to block AMPA and NMDA receptors, respectively. Whole-cell patch-clamp recordings using a Multiclamp 700A amplifier (Molecular Devices) were made from DGCs voltage-clamped at $+5 \mathrm{mV}$, unless otherwise stated, using patch-type pipette electrodes $(\sim 3-4 \mathrm{M} \Omega)$ containing the following (in mM): 131 Cs-gluconate, $8 \mathrm{NaCl}, 1 \mathrm{CaCl}_{2}, 10 \mathrm{EGTA}, 10$ glucose, and 10 HEPES; pH 7.4, 285-292 mmol/kg. All recordings were performed from DGCs whose somas were $<30 \mu \mathrm{m}$ from the molecular layer. For BAPTA experiments (Fig. 5A), $20 \mathrm{~mm}$ cesium gluconate, $10 \mathrm{~mm}$ EGTA, and $1 \mathrm{~mm} \mathrm{CaCl}_{2}$ were replaced with $20 \mathrm{~mm}$ BAPTA (osmolarity and $\mathrm{pH}$ adjusted with $\mathrm{CsOH}$ ). To isolate excitatory responses (Fig. $4 \mathrm{C}$ ), NBQX and D-APV were replaced with $100 \mu \mathrm{M}$ picrotoxin (PTX) to block $\mathrm{GABA}_{\mathrm{A}} \mathrm{Rs}$ and DGCs were voltage clamped at $-60 \mathrm{mV}$. Series resistance $(\sim 10-25 \mathrm{M} \Omega)$ was monitored throughout all experiments with a -5 $\mathrm{mV}, 80 \mathrm{~ms}$ voltage step, and cells that exhibited significant change in series resistance $(>20 \%)$ were excluded from analysis. To differentially stimulate inhibitory synaptic inputs, two monopolar-stimulating patchtype pipettes were filled with ACSF and placed in the dentate granule layer (DGL; $<20 \mu \mathrm{m}$ from the border with the molecular layer) to activate somatic inputs, and in the middle third of the molecular layer (MML) to stimulate dendritic inputs. Somatic extracellular field inhibitory synaptic potentials (fIPSPs) were recorded using pipettes filled with $1 \mathrm{M} \mathrm{NaCl}$ while the stimulating pipette was placed in the DGL. Stimulation intensity was adjusted to produce $0.2-0.4 \mathrm{mV}$ fIPSP amplitude. Exogenous GABA responses (Fig. $3 C$ ) were evoked by directly puffing GABA ( $1 \mathrm{~mm}, 25 \mathrm{~ms}, 2$ psi) using a Picospritzer III (Parker) connected to a patch pipette (resistance, 3-4 $\mathrm{m} \Omega$ ). The tip of the puffer pipette was positioned close to the recorded cell in the DGL or in the MML $\sim 30 \mu \mathrm{M}$ deep from the surface of the slice. All experiments and analyses using $\operatorname{Trp} v 1^{-/-}$and $C B 1 R^{-/-}$mice were performed in a blind fashion.

Except where indicated, pharmacological agents were bath applied after a stable baseline was established $(\sim 10-15 \mathrm{~min})$, and their effects were measured after responses reached a new steady state (typically $>15$ min). Stock solutions were prepared in water or DMSO and added to the ACSF as needed. Total DMSO in the ACSF was maintained at $<0.1 \%$. Drugs were obtained from Sigma and Tocris Bioscience, except WIN55, 212-2, D-APV, and NBQX, which were obtained from the NIMH Chemical Synthesis and Drug Supply Program. IPSCs were elicited every $20 \mathrm{~s}$, filtered at $2.4 \mathrm{kHz}$, and acquired at $5 \mathrm{kHz}$ using a custom-made software written in Igor Pro 4.09A (WaveMetrics). Statistical comparisons were made using paired and unpaired two-tailed Student's $t$ test and ANOVA at the $p<0.05$ significance level in OriginPro 7.0 and 8.6 (OriginLab). Unless otherwise indicated, all values are provided as the mean \pm SEM and illustrated traces are averages of 31-35 responses.

$A A V$-shRNA design and cloning. Trpv1 shRNA-1 (sense: GGCCAGGUAACUCUUACAACAGC) and TrpV1 shRNA-2 (sense: CGCUUGUAUAUGAUCAUCUUCA) with complete complementarity to the coding region of mouse (NM_001001445) and rat (NM_031982) sequences, and a nontargeting control shRNA (GAGGAUCAAAUUGAUAGUAAACC) with no sequence homology to any known gene transcript were designed. Desalted shRNA oligos containing a modified miR155 loop (GTTTTGGCCACTGACTGAC) and overhangs complementary to BamHI and XhoI restriction sites were custom synthesized (Invitrogen), annealed, and cloned into a "CreOff" AAV vector with a floxed cassette that comprises a U6 polymerase III promoter to drive shRNA expression, a CMV promoter to drive eGFP expression (Ventura et al., 2004) for identification of transduced neurons, and a woodchuck post-transcriptional response element to promote transgene expression. AAVs with serotype 9 were subsequently produced by Virovek using a baculovirus expression system (Chen, 2008).

$q R T-P C R$ and stereotaxic injection of Trpv1 AAV-shRNA constructs. For qRT-PCR, $\mathrm{GFP}^{+}$DGCs were suctioned with a patch pipette from acute slices and RNA was extracted by means of the Dynabeads mRNA direct micro kit (Invitrogen). Real-time quantitative qPCR was performed with TaqMan probes (Applied Biosystems) for Trpv1 (Rn00583117) and hypoxanthine phosphoribosyltransferase; RN01527838_g1 (Hprt). Reactions were run in triplicate in a StepOnePlus real-time PCR system (Applied Biosystems). mRNA abundance was calculated by means of the comparative cycle threshold method at a threshold of 0.02 . Data were analyzed using the software tool REST (http://www.REST.de.com/), on the basis of the group mean for the target transcript, versus reference Hprt transcript or Gapdh transcript.

For in vivo experiments Trpv1-shRNA was delivered by stereotaxic injection into the DG of live rats at P10 (Rodenas-Ruano et al., 2012) and all recorded neurons were assessed at P28-P35. Rats were placed in a stereotaxic frame and anesthetized with isoflurane and concentrated viral solution $(2 \mu \mathrm{l})$ was injected into the right DG $(3.4 \mathrm{~mm}$ posterior to bregma, $3.2 \mathrm{~mm}$ lateral to bregma, and $3.1 \mathrm{~mm}$ ventral from dura) at a flow rate of $0.2 \mu \mathrm{l} / \mathrm{min}$.

\section{Results}

\section{TRPV1 activation selectively depresses somatic inhibition onto DGCs}

To evaluate the role of TRPV1 on GABAergic inputs onto DGCs, putative somatic and dendritic IPSCs were monitored from the same cell (see Materials and Methods), and TRPV1 channels were activated with the specific agonist capsaicin (CAP; $2 \mu \mathrm{M}$ ). We found that CAP bath application selectively depressed somatic, but not dendritic IPSCs in rat (Somatic: $62.6 \pm 4.07 \%$ of baseline, $n=8, p<0.001$ paired $t$-test; Dendritic: $94.7 \pm 2.7 \%$ of baseline, $n=8, p>0.05$ paired $t$-test; Fig. $1 A)$. Subsequent application of the $\mathrm{GABA}_{\mathrm{A}} \mathrm{Rs}$ antagonist PTX $(100 \mu \mathrm{M})$ eliminated the CAPinsensitive component (Fig. 1A). CAP also depressed less invasive, PTX-sensitive, extracellular fIPSPs recorded in DGL (see Materials and Methods; fIPSP: $74.1 \pm 2.9 \%$ of baseline, $n=8$, $p<0.001$ paired $t$-test; Fig. $1 B)$. Pretreating slices $(\sim 10-20 \mathrm{~min})$ with two different TRPV1 antagonists, capsazepine (CPZ, $10 \mu \mathrm{M})$ or AMG9810 (AMG, $3 \mu \mathrm{M}$ ), eliminated CAP-mediated effects on somatic IPSCs compared with interleaved control slices (Control: $66.7 \pm 3.7 \%$ of baseline, $n=6$ vs CPZ: $94.5 \pm 1.4 \%$ of baseline, $n=7, p<0.001$ ANOVA and AMG: $95.2 \pm 1.6 \%$ of baseline, $n=$ $9, p<0.001$ ANOVA; Fig. $1 C)$. Moreover, this CAP-mediated effect on somatic inhibition was absent in slices from TRPV1 knock-out mice $\left(\operatorname{Trpv1} 1^{+/+}: 56.9 \pm 2.4 \%\right.$ of baseline, 3 animals, 8 cells; Trpv1 $1^{-/-}: 90.1 \pm 2.0 \%$ of baseline, 3 animals, 7 cells, $p<$ 
A

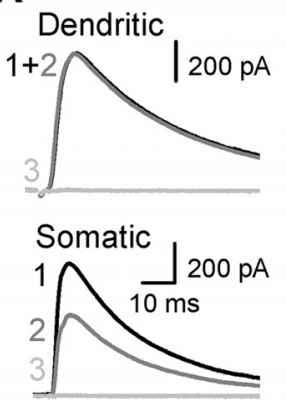

B
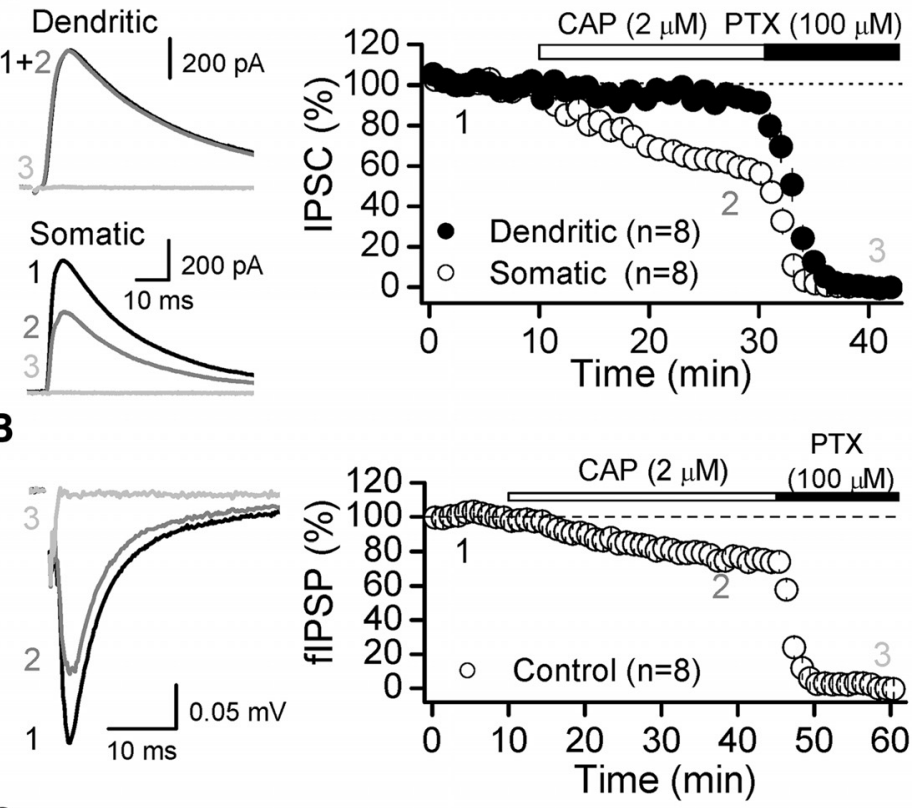

C
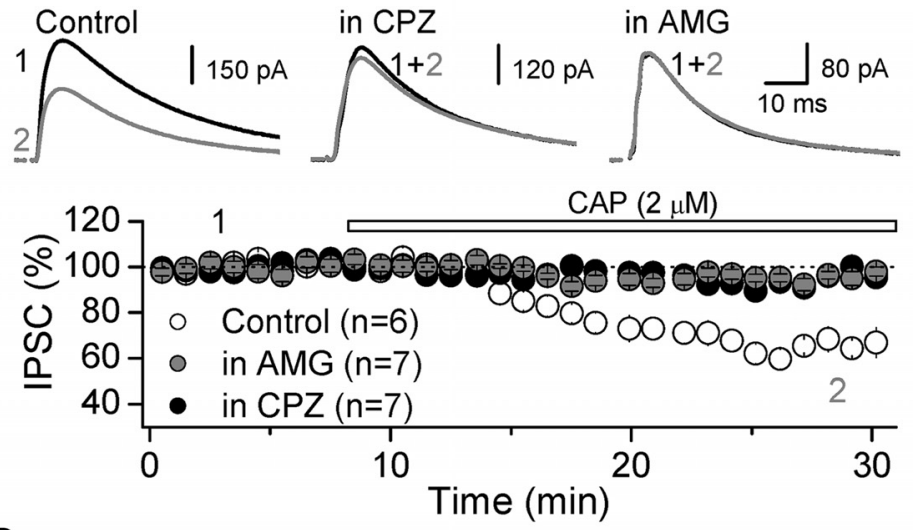

D
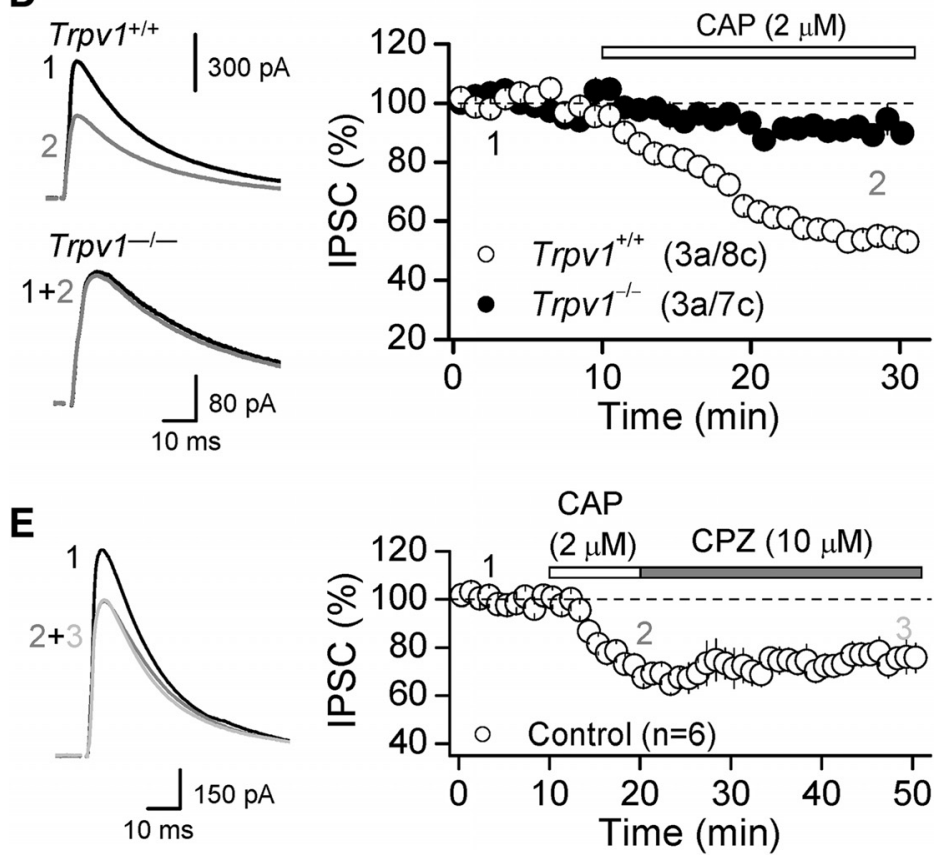

0.001 ANOVA; Fig. 1D). Finally, transient TRPV1 activation with CAP (for $10 \mathrm{~min}$ ), chased with $\mathrm{CPZ}$, induced a long-lasting suppression of somatic inhibitory transmission $(74.7 \pm 4.5 \%$ of baseline; $n=6$, $p<0.005$, paired $t$-test; Fig. $1 E)$. These results indicate that in DG, TRPV1 channels can suppress GABAergic synaptic transmission in a compartment-specific and longlasting manner.

TRPV1-mediated effects are CB1 receptor independent and likely postsynaptic in nature

We next investigated the mechanism by which TRPV1 activation depresses somatic GABAergic transmission. One possibility is that TRPV1 could indirectly depress somatic GABA release by mobilizing eCBs that activate presynaptic CB1Rs (Maccarrone et al., 2008). However, CB1R blockade with AM251 (4 $\mu \mathrm{M})$ had no effect on the CAP-mediated depression of somatic IPSCs (to $60.1 \pm 3.0 \%$ of baseline, $n=6, p<0.001$ paired $t$-test; Fig. 2A), whereas in interleaved experiments, AM251 abolished the depression of GABAergic transmission induced by the CB1R agonist WIN55, 212-2 (5 $\mu \mathrm{M}$; WIN: $50.2 \pm 4.0$ of baseline, $n=8$ vs WIN + AM251: $90.6 \pm 3.4$ of baseline, $n=4$, $p<0.001$ ANOVA; Fig. 2A). In addition, CAP-mediated depression was observed in both wild-type and CB1R knock-out mice $\left(\mathrm{CB} \mathrm{R}^{+/+}: 75.5 \pm 3.8 \%\right.$ of baseline, $n=6 ; \mathrm{CB}^{-1-}: 64.4 \pm 2.1 \%$ of baseline, $n=7$; Fig. $2 B$ ). Moreover, activation of TRPV1 channels with the eCB AEA $(30 \mu \mathrm{M})$, in the presence of the fatty acid amide hydrolase (FAAH) inhibitor

Figure 1. Functional expression of TRPV1 channels at inhibitory synapses in the dentate gyrus. $A$, Pharmacological activation of TRPV1 receptors with the agonist CAP $(2 \mu \mathrm{M})$ depressed GABAergic IPSCs in a compartment-specific manner. Left, Representative traces of GABAergic IPSCs before (black) and after (gray) bath application of CAP at both dendritic and somatic inputs (see Materials and Methods). Right, Summary plot showing the effect of CAP on IPSCs. Subsequent application of the $G_{A B A_{A}}$ Rs antagonist PTX (100 $\left.\mu \mathrm{m}\right)$ eliminated the CAP-insensitive component. $\boldsymbol{B}$, Somatic fIPSP was also depressed by bath application of CAP and eliminated by subsequent application of PTX. C, Pretreatment with the TRPV1 antagonist CPZ $(10 \mu \mathrm{M})$ or AMG $(3 \mu \mathrm{M})$ eliminated CAPmediated depression of somatic IPSCs. D, CAP suppression was observed in wild-type $\left(\operatorname{Trpv} 1^{+/+}\right)$, but not in TRPV1 knockdown mice (Trpv1 $\left.{ }^{-/-}\right)$. E, Transient application of CAP (2 $\mu \mathrm{m}$, $10 \mathrm{~min}$ ) followed by the TRPV1 antagonist CPZ (10 $\mu \mathrm{m})$ triggers a long-lasting suppression of inhibitory transmission in rat. Averaged sample traces taken at times indicated by numbers are shown next to each summary plot. In all parts, summary data represent the mean \pm SEM and the number of animals $(\boldsymbol{a})$ and cells $(\boldsymbol{c})$ are in parenthesis. 
URB597 $(1 \mu \mathrm{M})$ to block AEA degradation, and the CB1R antagonist AM251 (4 $\mu \mathrm{M})$, selectively depressed somatic, but not dendritic IPSCs (Somatic: $65.9 \pm$ $3.2 \%$ of baseline, $n=10, p<0.001$ paired $t$-test; Dendritic: $97.8 \pm 2.5 \%$ of baseline, $n=10, p=0.356$ paired $t$-test; Fig. $2 C$ ). This AEA-mediated depression was eliminated by two TRPV1 antagonists AMG (100.0 $\pm 3.8 \%$ of baseline, $n=6, p=$ 0.799 paired $t$-test) or CPZ (95.1 $\pm 2.7 \%$ of baseline, $n=3, p=0.220$ paired $t$-test; Fig. $2 C$ ). These results strongly argue that TRPV1-mediated depression of GABAergic transmission is CB1R independent.

To determine whether TRPV1 channels could directly depress GABA release, we examined the effects of CAP on both paired-pulse ratio (PPR; Fig. $3 A, B$ ) and coefficient of variation $\left(1 / \mathrm{CV}^{2}\right.$; Fig. $\left.3 A\right)$, two different measures that estimate changes in probability of release. Unlike WIN-mediated depression of inhibition (Fig. 3A), AEA- and CAP-mediated depression were not accompanied by significant changes in either PPR (Fig. $3 A, B$ ) or $1 / \mathrm{CV}^{2}$ (Fig. $3 A$ ) in both rat and mouse DG. It is therefore unlikely that a reduction in GABA release underlies AEAand CAP-mediated effects on inhibitory transmission. To directly test whether TRPV1 channels could act postsynaptically, we monitored GABAergic responses elicited by brief puffs of GABA (1 mM), a manipulation that shortcuts transmitter release. GABA-evoked responses (monitored at $0 \mathrm{mV}$ ) elicited by puffing in DGL (i.e., DGC soma), but not in MML (i.e., DGC dendrites), were significantly depressed by $2 \mu \mathrm{M}$ CAP (soma: $64.07 \pm$ $2.6 \%$ of baseline, $n=5, p<0.001$ paired $t$-test; dendrites: $100.47 \pm 3.3 \%$ of baseline, $n=5, p=0.890$ paired $t$-test; Fig. $3 C)$. At the end of each experiment, we confirmed that these responses were blocked by $100 \mu \mathrm{M}$ PTX (Fig. 3C). These results indicate that TRPV1 channels depress inhibitory synaptic transmission postsynaptically rather than by reducing GABA release.

In vivo knockdown of TRPV1 eliminates TRPV1-mediated effects on synaptic transmission

As a complementary approach to TRPV1 pharmacology, we used two different RNA interferences targeted to different Trpv1 regions to knockdown TRPV1 in DGCs. We stereotaxically injected synthetic shRNA targeted to TRPV1 (Trpv1 shRNA-1 and Trpv1 shRNA-2) or nontargeting shRNA directly into the rat DG (Fig. 4A; see Materials and Methods). Two to three weeks post injections, we
A
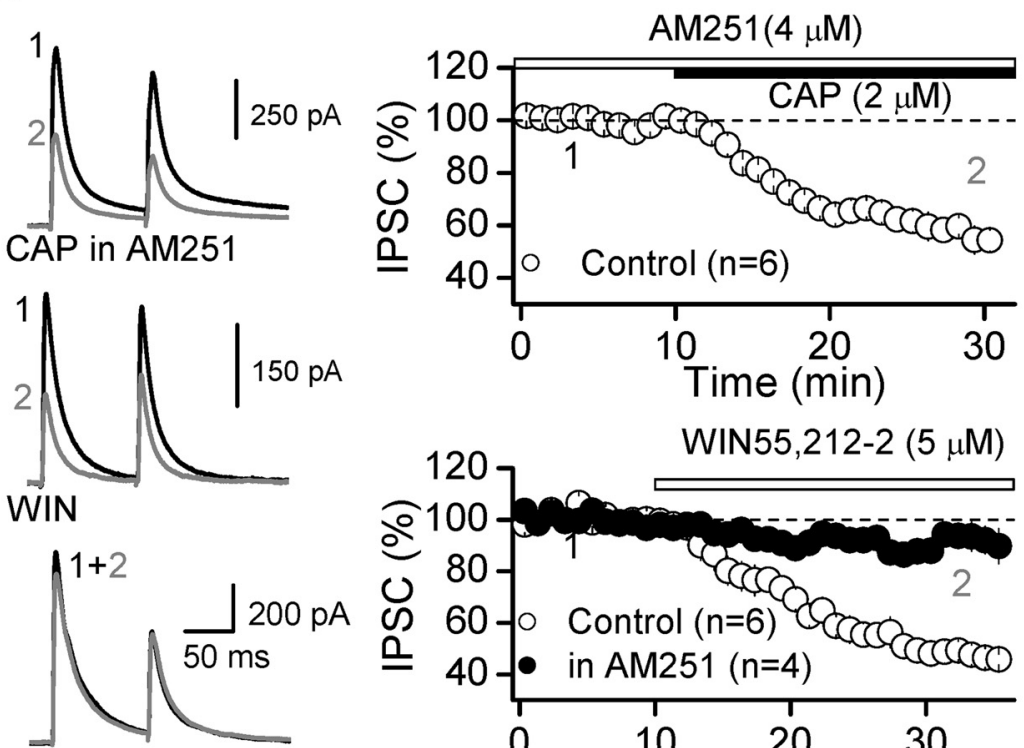

WIN in AM251

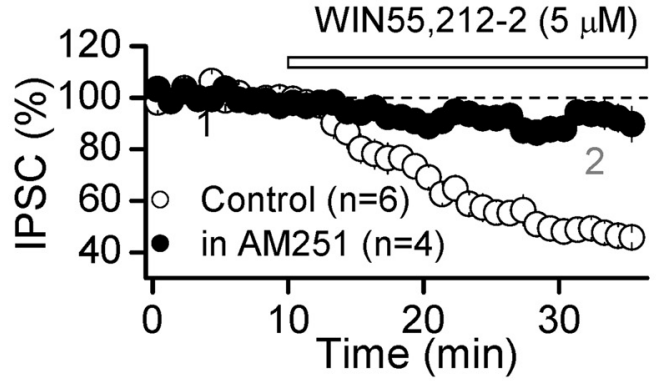

B
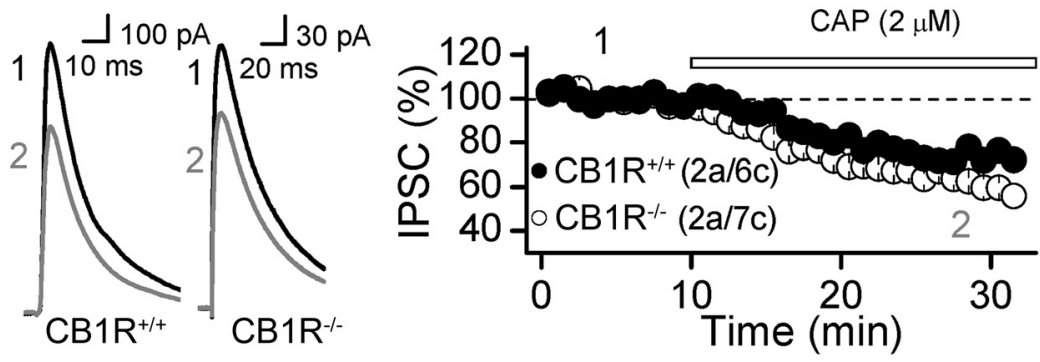

C
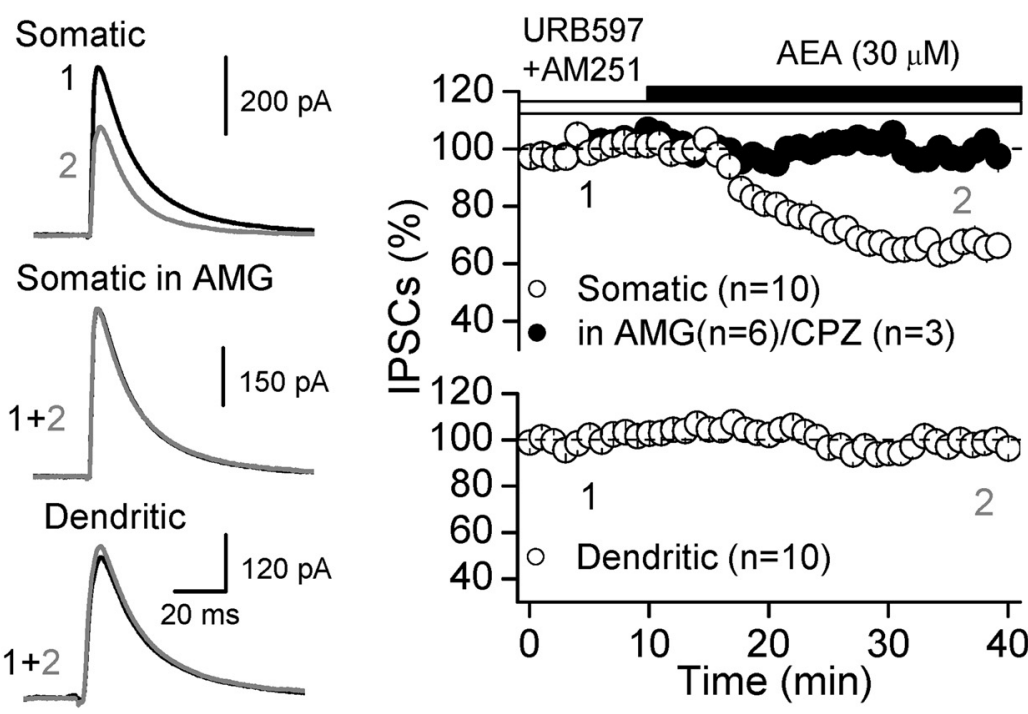

Figure 2. TRPV1 activation depresses inhibitory transmission in a CB1 receptor-independent manner. $\boldsymbol{A}$, Representative traces (left) and summary data (right) showing that bath application of $2 \mu \mathrm{M}$ CAP, while blocking CB1R with AM251 (4 $\mu \mathrm{M})$, depresses somatic IPSCs. In interleaved experiments (bottom), AM251 eliminated the depression of somatic IPSCs observed by bath application of the CB1R agonist WIN55, 212-2 (5 $\mu \mathrm{m})$. B, CAP-mediated depression was similar in both CB1R ${ }^{+1+}$ and CB1R $^{-1-}$ mouse, strongly suggesting that CAP depressing IPSCs was CB1R independent. C, Representative traces (left) and summary plots (right) showing that bath application of the eCBs AEA (30 $\mu \mathrm{m}$ ) selectively reduced somatic (top), but not dendritic IPSCs (bottom). AEA-mediated depression was eliminated by pretreatment of the slices with TRPV1 antagonist, CPZ or AMG. Summary data represent the mean \pm SEM and the number of animals $(\boldsymbol{a})$ and cells $(\boldsymbol{c})$ are in parenthesis. 
A

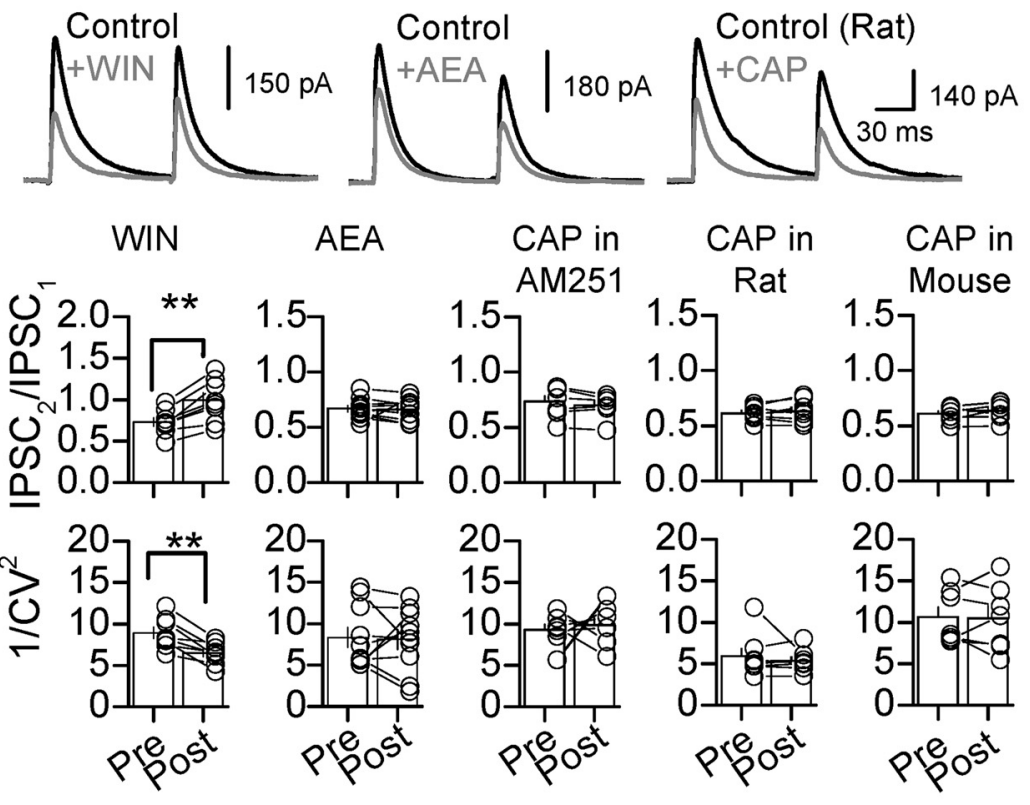

B
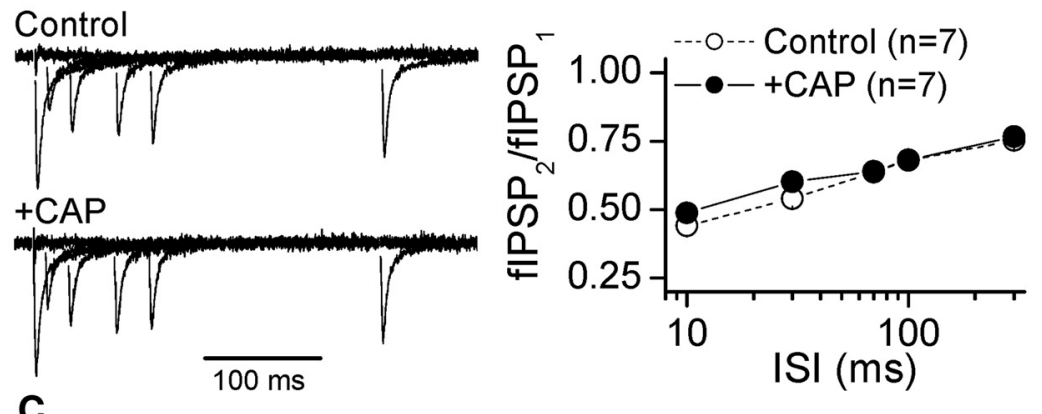

C
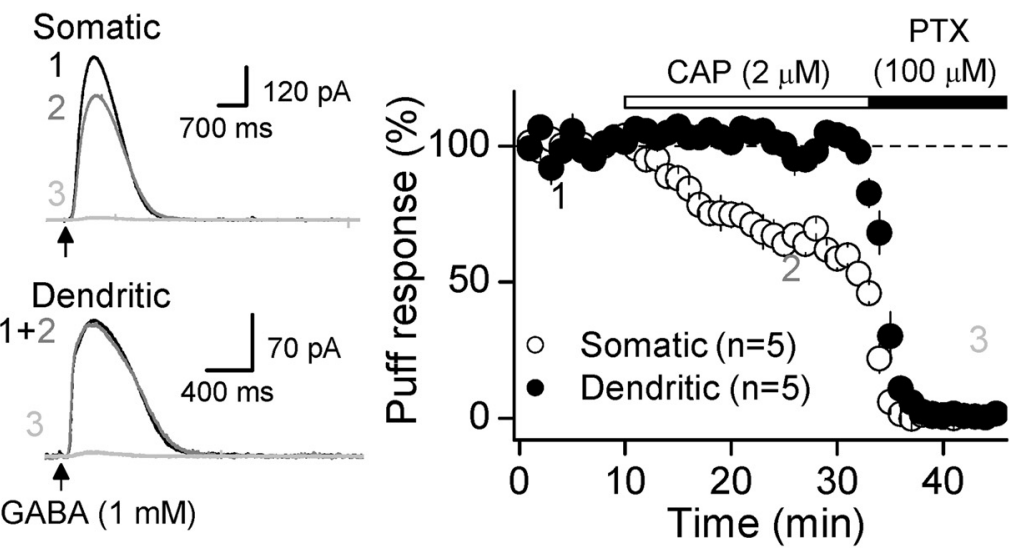

Figure 3. TRPV1-mediated depression of inhibition is postsynaptic. $\boldsymbol{A}$, Top, Representative traces of two consecutive GABAergic IPSCs (100 ms interstimulus interval) before (black) and after (gray) bath application of WIN, AEA, and CAP. Bottom, Summary plots showing that WIN, but not AEA or CAP, significantly changes the PPR and $1 / \mathrm{CV}^{2}$ of somatic IPSCs. These results were generated from the experiments reported in Figure $1 A$ and $D$ and Figure $2 A$ and $C . B$, CAP did not alter PPR of fIPSPs recorded as in Figure $1 B$ and measured at different interstimulus intervals $(10,30,75,100$, and $300 \mathrm{~ms})$. fIPSPs were normalized to the first response. $C$, Representative traces (left) and summary plot (right) showing that CAP also mediated depression of GABAR-mediated responses evoked by puffing GABA (1 mM, $25 \mathrm{~ms}$ ) in the DGL (somatic) but not in the middle third of the molecular layer (dendritic). Subsequent application of PTX (100 $\mu \mathrm{m})$ eliminated the CAP-insensitive component of GABA-evoked responses. In all cases, averaged sample traces taken at times indicated by numbers are shown next to each summary plot. Summary data represent the mean \pm SEM. ${ }^{* *} p<0.01$. validated the efficacy of the TRPV1 knockdown by suctioning DGCs from hippocampal slices using a patch-type pipette and obtaining samples enriched with $\mathrm{GFP}^{+}$-expressing neurons. Despite the presence of $\mathrm{GFP}^{-}$cells in our sample, qRT-PCR analysis revealed that the levels of Trpv1 mRNA in DGCs were significantly reduced by both Trpv1 shRNA-1 and Trpv1 shRNA-2 relative to nontransduced control cells (Trpv1 shRNA-1: $40 \pm$ $9.0 \%$ of control, three animals, $p=0.008$, Trpv1 shRNA-2: $55.8 \pm 6.5 \%$ of control, 6 animals, $p=0.001$; see Materials and Methods; Fig. 4B). To assess the functional impact of knocking down TRPV1 in DGCs, we first examined excitatory synaptic inputs (i.e., MPP synapses) where we previously reported that TRPV1 activation suppresses transmission (Chávez et al., 2010). We found that CAP-mediated depression of AMPARs-EPSCs was similar between nontargeting shRNA and nontransduced neurons and thus, these neurons were pooled for further analysis ( 9 nontargeting vs 10 nontransduced cells; $p=0.98$ ANOVA; Fig. 4C). In contrast, the CAPmediated depression was significantly reduced in neurons expressing Trpv1 shRNA-1 (94.6 $\pm 3.0 \%$ of baseline, 5 animals/9 cells; Fig. $4 C$ ) or Trpv1 shRNA-2 (93.7 $\pm 4.9 \%$ of baseline, 4 animals/ 10 cells; Fig. 4C) when compared with control neurons $(60.2 \pm 3.2 \%$ of baseline, 9 animals/19 cells; Control vs Trpv1 shRNA-1 or Trpv2 shRNA-2, $p<0.001$, ANOVA; Fig. 4C). Importantly, we also found that CAP-mediated depression of GABAergic transmission was reduced in neurons expressing Trpv1 shRNA-1 $(83.4 \pm 4.6 \%$ of baseline, 6 animals $/ 13$ cells) and Trpv1 shRNA-2 (88.7 $\pm 3.0 \%$ of baseline, 6 animals/12 cells) when compared with nontransduced control neurons recorded in interleaved experiments (control: $51.2 \pm 6.8 \%$ of baseline, 5 animals/ 6 cells; shRNA-1 vs Control $p=$ 0.001 ANOVA; shRNA-2 vs Control $p<$ 0.001 , ANOVA; Fig. $4 D$ ). Thus, our findings using complementary TRPV1 knockdown (Fig. 4) and selective pharmacology (Figs. 1-3) demonstrate that activation of TRPV1 channels in DGCs depresses both excitatory and inhibitory transmission by regulating postsynaptic AMPA and GABA receptors, respectively.

Mechanisms underlying TRPV1mediated suppression of inhibition At excitatory synapses, TRPV1 reduces transmission by promoting postsynaptic $\mathrm{Ca}^{2+}$ rise and clathrin/dynamin-dependent endocytosis of AMPARs (Chávez et al., 2010; 
Grueter et al., 2010). Because GABA Rs can alsobeendocytosed in a clathrin/dynamindependent manner (Luscher et al., 2011), we next tested whether internalization of $\mathrm{GABA}_{\mathrm{A}} \mathrm{Rs}$ might underlie TRPV1mediated depression of somatic inhibitory transmission. First, we evaluated the requirement of postsynaptic $\mathrm{Ca}^{2+}$ rise by loading DGCs with the $\mathrm{Ca}^{2+}$ chelator BAPTA $(20 \mathrm{~mm})$. Under this condition, CAP failed to depress GABAergic transmission compared with interleaved control neurons (BAPTA: $98.1 \pm 2.7 \%$ of baseline, $n=8, p=0.419$ paired $t$-test; Control: $62.1 \pm 3.3 \%$ of baseline, $n=7$, $p<0.001$ paired $t$-test; BAPTA vs Control: $p<0.001$ ANOVA; Fig. $5 A$ ). In addition, pretreatment of slices with $30 \mu \mathrm{M}$ cyclopiazonic acid (CPA), a manipulation aimed to deplete intracellular $\mathrm{Ca}^{2+}$ stores, significantly reduced CAP-mediated depression of somatic IPSCs compared with interleaved control neurons (CPA: $80.1 \pm$ $1.7 \%, n=11$, CPA vs Control: $p<0.001$ ANOVA; Fig. 5A). In interleaved experiments, CPA did not affect basal synaptic transmission $(98.7 \pm 8.1 \%$ of control, $n=$ $4, p=0.898$ paired $t$ test; Fig. $5 A$, bottom). Next, we tested whether the $\mathrm{Ca}^{2+}$ / calmodulin-dependent protein phosphatase calcineurin $(\mathrm{CaN})$ could also participate in the TRPV1-mediated suppression of GABAergic transmission, as we previously reported at excitatory synapses in the DG (Chávez et al., 2010). Pretreatment of slices for $30 \mathrm{~min}$ with CaN inhibitors, FK506 (50 $\mu \mathrm{M})$ and Cyclosporin A (CyA; $25 \mu \mathrm{M})$ eliminated CAP-mediated depression of GABAergic transmission compared with control slices (Control: $62.6 \pm 2.5 \%$ of baseline, $n=9$ vs FK506: $92.0 \pm 3.5 \%$ of baseline, $n=7, p<0.001$ ANOVA; CyA: $94.0 \pm$ $3.0 \%$ of baseline, $n=7, p<0.001$ ANOVA; Fig. 5B). Application of FK506 and CyA for 30 min did not affect basal synaptic transmission (FK506: $98.6 \pm$ $3.7 \%$ of baseline, $n=6, p=0.538$, paired $t$ test; CyA: to $100.5 \pm 6.1 \%$ of baseline, $n=7, p=0.998$, paired $t$ test; Fig. $5 B$, bottom). Finally, we investigated whether dynamin-dependent endocytosis of $\mathrm{GABA}_{\mathrm{A}}$ Rs could be involved in the TRPV1-mediated depression of inhibitory transmission. To test this possibility, we loaded DGCs with the dynamin inhibitory peptide (DIP; $50 \mu \mathrm{M}$ ), and found that this peptide significantly reduced CAP-mediated depression of inhibition compared with a scrambled DIP (DIP: $92.7 \pm 4.9 \%$ of baseline, $n=10$ vs scrambled DIP: $59.3 \pm 6.5 \%$ of baseline, $n=7$, $p<0.001$, ANOVA; Fig. 5D). Thus, our
A

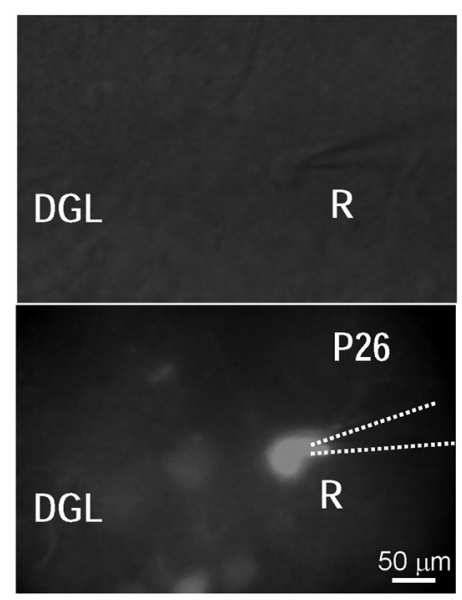

B

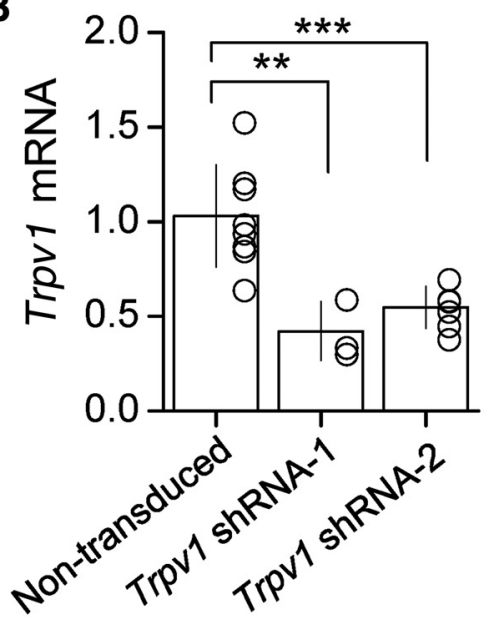

C

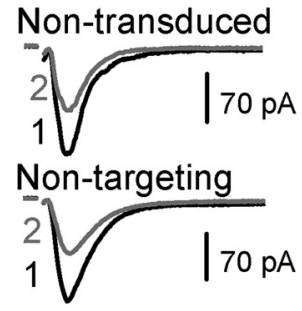

Trpv1 shRNA-1

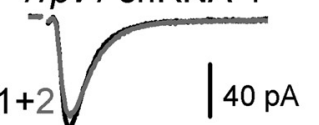

Trpv1 shRNA-2
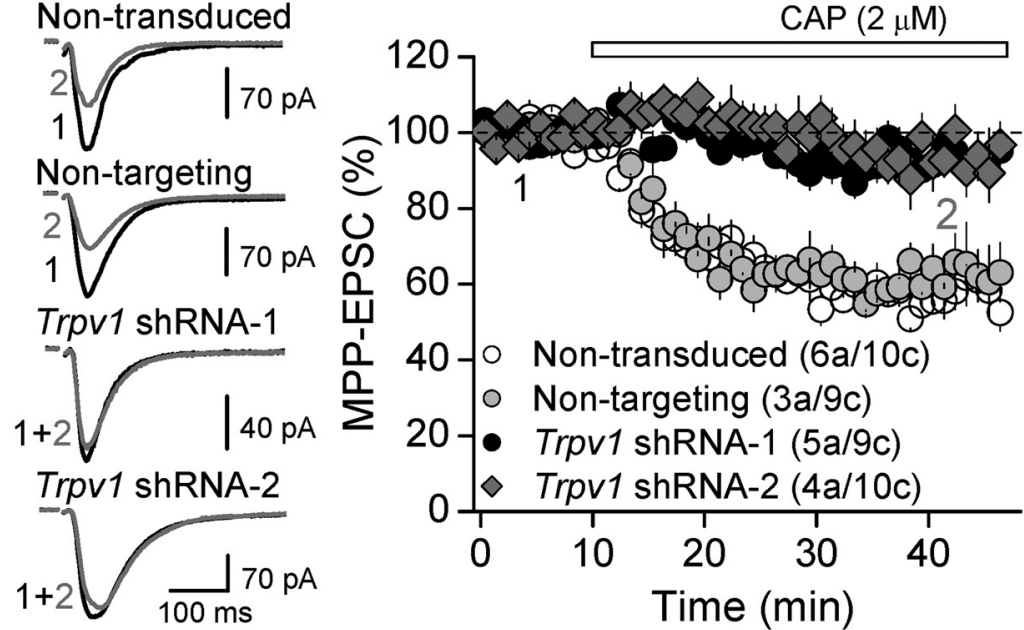

D

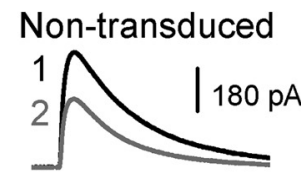

Trpv1 shRNA-1


Figure 4. In vivo knockdown of TRPV1 abolishes TRPV1-mediated depression of synaptic transmission in the DG. A, Differential interference contrast (top) and fluorescence (bottom) images showing whole-cell recordings from Trpv1 shRNA-expressing $\left(G_{F P}^{+}\right)$DGCs. R, recording pipette. B, Trpv1 mRNA levels following Trpv1 shRNA-1 and Trpv1 shRNA-2 injection, at P10 and assessed by qRT-PCR at P28 -32 in isolated DGCs, were significantly different compared with nontransduced control cells. $C$, Representative traces (left) and summary data (right) showing that CAP-mediated depression of AMPA-mediated EPSC elicited at the medial perforant path (MPP)-DG synapse was eliminated in both Trpv1 shRNA-1 and Trpv1 shRNA-2-expressing DGCs compared with DGCs expressing nontargeting shRNA or nontransduced cells. D, Both Trpv1 shRNA-1 and Trpv1 shRNA-2 significantly reduce CAP-mediated depression of somatic GABAergic IPSCs. In all parts, averaged sample traces taken at times indicated by numbers are shown next to each summary plot and summary data represent the mean \pm SEM. The number of animals $(\boldsymbol{a})$ and cells (c) are in parenthesis; ${ }^{* *} p=0.008 ;{ }^{* *} p=0.001$. 
A

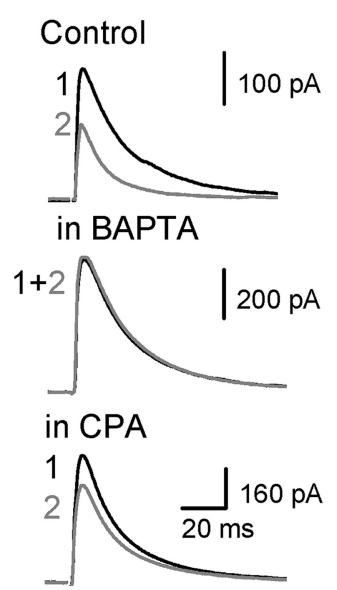

B
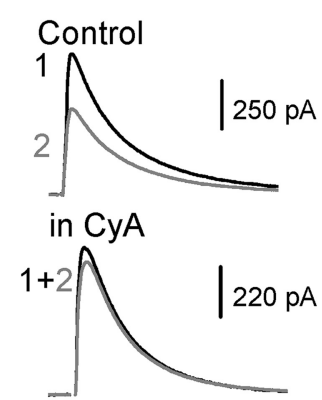

in FK506

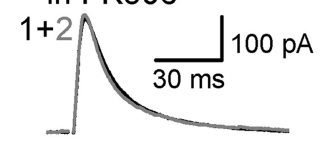

C

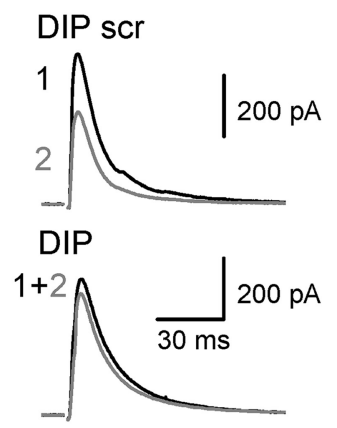

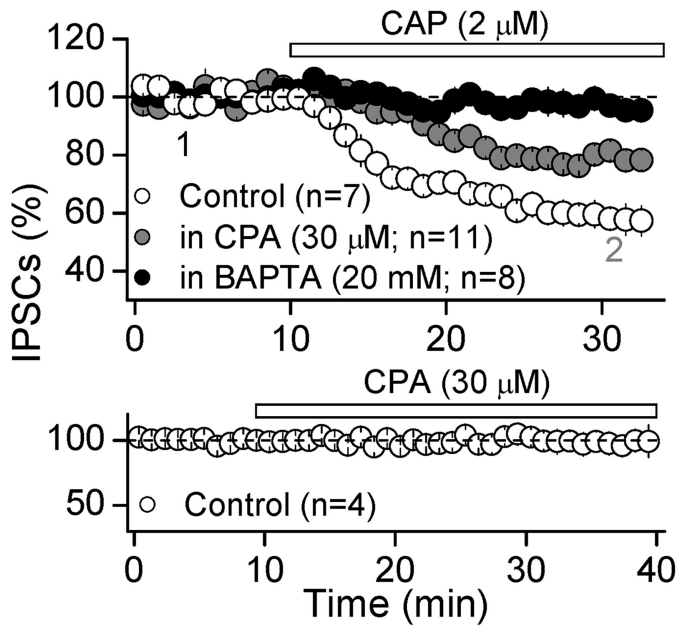
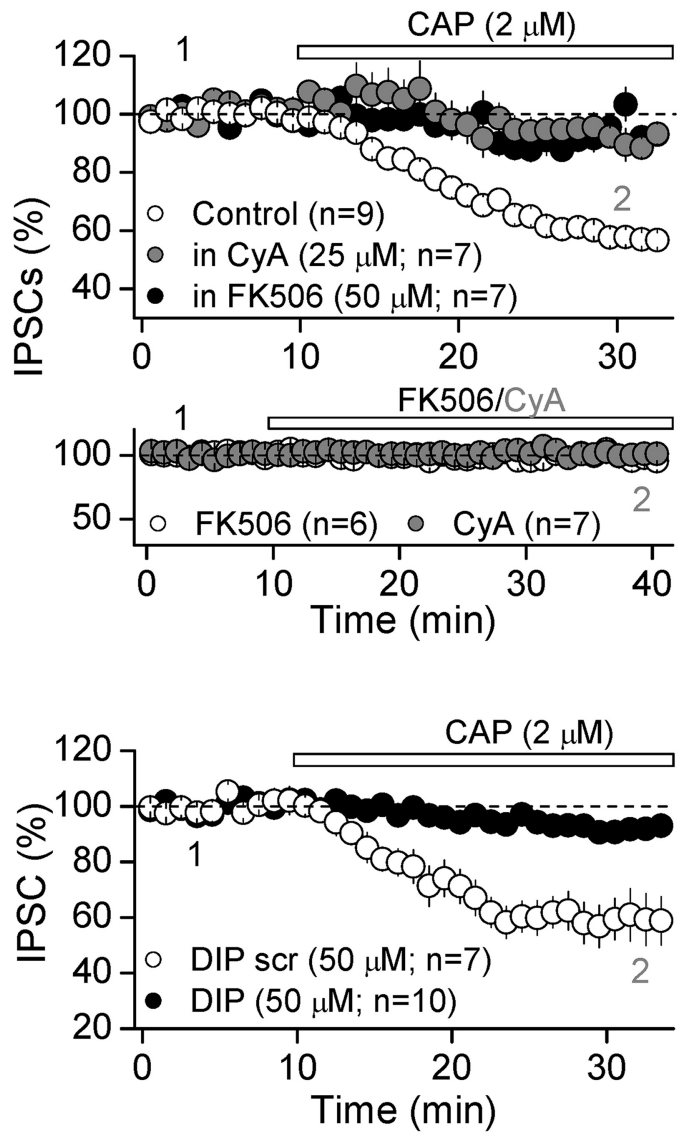

Figure 5. Mechanism underlying TRPV1-mediated depression of inhibitory transmission. $\boldsymbol{A}$, Representative traces (left) and summary plot (right) showing that loading DGCs with BAPTA $(20 \mathrm{~mm})$ completely eliminated, whereas pre-incubation with $30 \mu \mathrm{M}$ CPA significantly reduces, CAP-mediated depression of GABAergic IPSCs. Note that bath application of CPA for at least 30 min did not affect basal synaptic transmission (bottom). $\boldsymbol{B}$, Representative traces (left) and summary plot (right) showing that two different calcineurin inhibitors, FK506 $(50 \mu \mathrm{m})$ and CyA $(25 \mu \mathrm{m})$, eliminated CAP-mediated depression of inhibition. Bath application of FK506 or CyA for 30 min did not affect GABAergic basal synaptic transmission (bottom). C, Intracellular loading of DIP (50 $\mu \mathrm{M})$, but not DIP scrambled (DIP scr; $50 \mu \mathrm{M}$ ), eliminated (AP-mediated depression. Averaged sample traces taken at times indicated by numbers are shown next to each summary plot. In all parts, summary data represent the mean \pm SEM and the number of cells tested is in parenthesis.

results strongly suggest that activation of TRPV1 channels leads to an increase in postsynaptic $\mathrm{Ca}^{2+}$ rise which, by activating the $\mathrm{CaN}$-dynamin complex, likely promotes $\mathrm{GABA}_{\mathrm{A}} \mathrm{Rs}$ endocytosis.

\section{Discussion}

The results presented in this study demonstrate that TRPV 1 channels, in addition to modulating excitatory synaptic inputs (Chávez et al., 2010; Grueter et al., 2010; Puente et al., 2011), can also target inhibitory synapses in rat and mouse DG. We report that activation of TRPV1 channels, presumably by promoting internalization of $\mathrm{GABA}_{\mathrm{A}} \mathrm{Rs}$, selectively depresses somatic but not dendritic GABAergic synaptic inputs onto DGCs. We also show that the eCB AEA depresses inhibitory synaptic transmission by targeting TRPV 1 channels, and this effect can occur while CB1Rs are pharmacologically blocked. To our knowledge, we provide the first evidence that TRPV1 channels can directly regulate inhibitory transmission at central synapses.

In the CNS, there is good evidence that activation of TRPV1 channels regulates excitatory transmission either presynaptically by modulating glutamate release (for review, see Kauer and Gibson, 2009), or postsynaptically by promoting AMPAR removal from the synapse (Chávez et al., 2010; Grueter et al., 2010; Kim et al., 2012). In contrast, previous attempts have not identified any effect of TRPV1 activation on synaptic inhibition (Yang et al., 1998; Marinelli et al., 2003; D.P. Li et al., 2004; Xing and Li, 2007). Our finding that TRPV1 channels suppress somatic but not dendritic inhibitory inputs (Figs. 1, 2) is reminiscent of previous observations showing that the TRPV1-mediated depression of excitatory transmission occurs at some synaptic inputs but not others (Chávez et al., 2010; Grueter et al., 2010; Puente et al., 2011). Thus, input specificity could be a general property of TRPV1mediated effects throughout the brain.

The precise mechanism underlying input specificity of TRPV1-mediated suppression of synaptic transmission is unclear. For example, it could reflect the selective expression of TRPV1 channels at some synapses, although spatially constrained signaling downstream of TRPV1 channels may also contribute. In support of TRPV1 synaptic segregation, a recent anatomical immunoelectron microscopy study in DG showed that TRPV1 is highly concentrated in postsynaptic dendritic spines receiving perforant path inputs, whereas expression is weak at more proximal excitatory hilar mossy cell synapses (Puente et al., 2014). This subcellular anatomical distribution is consistent with the selective TRPV1mediated suppression of excitatory transmission at medial perforant path but not hilar mossy cell synapses (Chávez et al., 
2010). GABAergic interneurons in the DG comprise a diverse group of cell types (Houser, 2007) with domain-specific innervation and distinct functional properties (Z.S. Han et al., 1993; Hefft and Jonas, 2005; Liu et al., 2014), raising the possibility that TRPV1 channels also could be expressed at subtypes of inhibitory synapses. Regardless of the precise synapse type, by selectively suppressing somatic inhibition, TRPV1 channels may control DGC spike initiation (Miles et al., 1996). The fact that TRPV1 channels modulate both excitatory (Chávez et al., 2010) and inhibitory transmission in a compartment-specific manner indicates that TRPV1 might play a subtle role in regulating synaptic integration and DGC output. While exogenous activation of TRPV1 channels is expected to suppress both excitatory and inhibitory inputs onto DGCs, it remains to be seen whether both actions can occur simultaneously by endogenous TRPV1 activation.

TRPV1 can be activated by lipid messengers such as the eCB AEA (Ross, 2003). Typically, eCBs are mobilized from the postsynaptic compartment and act retrogradely to suppress transmitter release by activating presynaptic CB1Rs (Kano et al., 2009; Castillo et al., 2012), and in most synapses, this form of retrograde signaling is likely mediated by the eCB 2-AG (OhnoShosaku and Kano, 2014). Growing evidence, however, indicates that eCBs can also regulate synaptic function in an unconventional manner by activating postsynaptic TRPV1 channels (Castillo et al., 2012). Our findings that AEA regulates GABAergic transmission in a postsynaptic and CB1R-independent manner provide further support for this way of regulating synaptic function via eCBs. Previous work in the DG showed that retrograde eCB signaling suppresses GABA release (Isokawa and Alger, 2005), suggesting eCB-mediated modulation of synaptic inhibition is complex. In addition, AEA acting on TRPV1 channels could facilitate 2-AG production and by this means suppress synaptic inhibition via CB1Rs, as previously reported in dorsal striatum (Maccarrone et al., 2008). However, we show that AEA in the DG suppresses GABAergic transmission in a CB1R-independent manner by activating TRPV1 channels. It has recently been reported that specific patterns of activity mobilizes AEA or 2-AG from the same neuron and, by activating postsynaptic TRPV1 channels or presynaptic CB1Rs, respectively, these eCBs trigger mechanistically different forms of long-term depression (LTD) at excitatory synapses (Grueter et al., 2010; Puente et al., 2011). Whether endogenous activation of TRPV1 and CB1Rs can trigger similar forms of long-term plasticity at inhibitory synapses remains to be determined.

Recent studies have shown that activation of TRPV1 channels promotes AMPAR internalization at excitatory synapses in the DG (Chávez et al., 2010), nucleus accumbens (Grueter et al., 2010), and spinal cord (Kim et al., 2012). In the DG, we have reported that TRPV1-mediated endocytosis of AMPARs occurs in a CaN/dynamin-dependent manner (Chávez et al., 2010), and our new findings indicate that this mechanism also operates for GABA $_{\mathrm{A}}$ Rs (Fig. 5). Notably, CaN has been involved in TRPV1mediated downregulation of voltage-gated $\mathrm{Ca}^{2+}$ channels in primary sensory neurons (Wu et al., 2005) and TRPV1-induced LTD in hippocampal interneurons (Jensen and Edwards, 2012). Together, these observations substantiate the notion that $\mathrm{CaN}$ is a common downstream target of TRPV1-mediated effects.

In summary, our data provide further evidence in support of functional TRPV1 channels as regulators of synaptic transmission in the CNS. Such regulation, at least in DG, is input specific, includes excitatory and inhibitory synapses, and could play a role in controlling the relative weight of excitatory and inhibitory inputs. Although our understanding of brain TRPV1 in vivo is currently rather limited, studies using TRPV1 knock-out mice suggest that this channel might be involved in drug addiction (Grueter et al., 2010), anxiety, and fear condition (Marsch et al., 2007). In addition, TRPV1 protein levels are reportedly increased in the DG of an animal model of epilepsy (Bhaskaran and Smith, 2010), suggesting that TRPV1 could be regulated by aberrant neural activity. Brain TRPV1-mediated actions deserve attention given that TRPV1 antagonism has emerged as an alternative strategy for pain management. Additional work is necessary to fully understand under what conditions TRPV1 modulates excitatory and inhibitory inputs and ultimately, to determine how exactly modulation of these inputs affects brain function.

\section{References}

Aguiar DC, Terzian AL, Guimarães FS, Moreira FA (2009) Anxiolytic-like effects induced by blockade of transient receptor potential vanilloid type 1 (TRPV1) channels in the medial prefrontal cortex of rats. Psychopharmacology 205:217-225. CrossRef Medline

Bennion D, Jensen T, Walther C, Hamblin J, Wallmann A, Couch J, Blickenstaff J, Castle M, Dean L, Beckstead S, Merrill C, Muir C, St Pierre T, Williams B, Daniel S, Edwards JG (2011) Transient receptor potential vanilloid 1 agonists modulate hippocampal CA1 LTP via the GABAergic system. Neuropharmacology 61:730-738. CrossRef Medline

Bhaskaran MD, Smith BN (2010) Effects of TRPV1 activation on synaptic excitation in the dentate gyrus of a mouse model of temporal lobe epilepsy. Exp Neurol 223:529-536. CrossRef Medline

Castillo PE, Younts TJ, Chávez AE, Hashimotodani Y (2012) Endocannabinoid signaling and synaptic function. Neuron 76:70-81. CrossRef Medline

Caterina MJ, Julius D (2001) The vanilloid receptor: a molecular gateway to the pain pathway. Annu Rev Neurosci 24:487-517. CrossRef Medline

Caterina MJ, Schumacher MA, Tominaga M, Rosen TA, Levine JD, Julius D (1997) The capsaicin receptor: a heat-activated ion channel in the pain pathway. Nature 389:816-824. CrossRef Medline

Cavanaugh DJ, Chesler AT, Jackson AC, Sigal YM, Yamanaka H, Grant R, O’Donnell D, Nicoll RA, Shah NM, Julius D, Basbaum AI (2011) Trpv1 reporter mice reveal highly restricted brain distribution and functional expression in arteriolar smooth muscle cells. J Neurosci 31:5067-5077. CrossRef Medline

Chávez AE, Chiu CQ, Castillo PE (2010) TRPV1 activation by endogenous anandamide triggers postsynaptic long-term depression in dentate gyrus. Nat Neurosci 13:1511-1518. CrossRef Medline

Chen H (2008) Intron splicing-mediated expression of AAV Rep and Cap genes and production of AAV vectors in insect cells. Mol Ther 16:924930. CrossRef Medline

Cristino L, de Petrocellis L, Pryce G, Baker D, Guglielmotti V, Di Marzo V (2006) Immunohistochemical localization of cannabinoid type 1 and vanilloid transient receptor potential vanilloid type 1 receptors in the mouse brain. Neuroscience 139:1405-1415. CrossRef Medline

Derbenev AV, Monroe MJ, Glatzer NR, Smith BN (2006) Vanilloid-mediated heterosynaptic facilitation of inhibitory synaptic input to neurons of the rat dorsal motor nucleus of the vagus. J Neurosci 26:9666-9672. CrossRef Medline

Ferrini F, Salio C, Vergnano AM, Merighi A (2007) Vanilloid receptor-1 (TRPV1)-dependent activation of inhibitory neurotransmission in spinal substantia gelatinosa neurons of mouse. Pain 129:195-209. CrossRef Medline

Gibson HE, Edwards JG, Page RS, Van Hook MJ, Kauer JA (2008) TRPV1 channels mediate long-term depression at synapses on hippocampal interneurons. Neuron 57:746-759. CrossRef Medline

Grueter BA, Brasnjo G, Malenka RC (2010) Postsynaptic TRPV1 triggers cell type-specific long-term depression in the nucleus accumbens. Nat Neurosci 13:1519-1525. CrossRef Medline

Han P, Korepanova AV, Vos MH, Moreland RB, Chiu ML, Faltynek CR (2013) Quantification of TRPV1 protein levels in rat tissues to understand its physiological roles. J Mol Neurosci 50:23-32. CrossRef Medline

Han ZS, Buhl EH, Lörinczi Z, Somogyi P (1993) A high degree of spatial selectivity in the axonal and dendritic domains of physiologically identi- 
fied local-circuit neurons in the dentate gyrus of the rat hippocampus. Eur J Neurosci 5:395-410. CrossRef Medline

Hefft S, Jonas P (2005) Asynchronous GABA release generates long-lasting inhibition at a hippocampal interneuron-principal neuron synapse. Nat Neurosci 8:1319-1328. CrossRef Medline

Houser CR (2007) Interneurons of the dentate gyrus: an overview of cell types, terminal fields and neurochemical identity. Prog Brain Res 163: 217-232. CrossRef Medline

Huang SM, Bisogno T, Trevisani M, Al-Hayani A, De Petrocellis L, Fezza F, Tognetto M, Petros TJ, Krey JF, Chu CJ, Miller JD, Davies SN, Geppetti P, Walker JM, Di Marzo V (2002) An endogenous capsaicin-like substance with high potency at recombinant and native vanilloid VR1 receptors. Proc Natl Acad Sci U S A 99:8400-8405. CrossRef Medline

Huang WX, Min JW, Liu YQ, He XH, Peng BW (2014) Expression of TRPV1 in the C57BL/6 mice brain hippocampus and cortex during development. Neuroreport 25:379-385. CrossRef Medline

Isokawa M, Alger BE (2005) Retrograde endocannabinoid regulation of GABAergic inhibition in the rat dentate gyrus granule cell. J Physiol 567: 1001-1010. CrossRef Medline

Jensen T, Edwards JG (2012) Calcineurin is required for TRPV1-induced long-term depression of hippocampal interneurons. Neurosci Lett 510: 82-87. CrossRef Medline

Kano M, Ohno-Shosaku T, Hashimotodani Y, Uchigashima M, Watanabe M (2009) Endocannabinoid-mediated control of synaptic transmission. Physiol Rev 89:309-380. CrossRef Medline

Kauer JA, Gibson HE (2009) Hot flash: TRPV channels in the brain. Trends Neurosci 32:215-224. CrossRef Medline

Kim YH, Back SK, Davies AJ, Jeong H, Jo HJ, Chung G, Na HS, Bae YC, Kim SJ, Kim JS, Jung SJ, Oh SB (2012) TRPV1 in GABAergic interneurons mediates neuropathic mechanical allodynia and disinhibition of the nociceptive circuitry in the spinal cord. Neuron 74:640-647. CrossRef Medline

Köles L, Garção P, Zádori ZS, Ferreira SG, Pinheiro BS, Da Silva-Santos CS, Ledent C, Köfalvi A (2013) presyntaptic TRPV1 vanilloid receptor function is age- but not CB1 cannabinoid receptor-dependent in the rodent forebrain. Brain Res Bull 97:126-135. CrossRef Medline

Li DP, Chen SR, Pan HL (2004) VR1 receptor activation induces glutamate release and postsynaptic firing in the paraventricular nucleus. J Neurophysiol 92:1807-1816. CrossRef Medline

Li HB, Mao RR, Zhang JC, Yang Y, Cao J, Xu L (2008) Antistress effect of TRPV1 channel on synaptic plasticity and spatial memory. Biol Psychiatry 64:286-292. CrossRef Medline

Liao HT, Lee HJ, Ho YC, Chiou LC (2011) Capsaicin in the periaqueductal gray induces analgesia via metabotropic glutamate receptor-mediated endocannabinoid retrograde disinhibition. Br J Pharmacol 163:330-345. CrossRef Medline

Liu YC, Cheng JK, Lien CC (2014) Rapid dynamic changes of dendritic inhibition in the dentate gyrus by presynaptic activity patterns. J Neurosci 34:1344-1357. CrossRef Medline

Luscher B, Fuchs T, Kilpatrick CL (2011) GABAA receptor traffickingmediated plasticity of inhibitory synapses. Neuron 70:385-409. CrossRef Medline

Maccarrone M, Rossi S, Bari M, De Chiara V, Fezza F, Musella A, Gasperi V, Prosperetti C, Bernardi G, Finazzi-Agrò A, Cravatt BF, Centonze D (2008) Anandamide inhibits metabolism and physiological actions of 2-arachidonoylglycerol in the striatum. Nat Neurosci 11:152-159. CrossRef Medline

Maione S, Cristino L, Migliozzi AL, Georgiou AL, Starowicz K, Salt TE, Di Marzo V (2009) TRPV1 channels control synaptic plasticity in the developing superior colliculus. J Physiol 587:2521-2535. CrossRef Medline

Marinelli S, Vaughan CW, Christie MJ, Connor M (2002) Capsaicin activation of glutamatergic synaptic transmission in the rat locus coeruleus in vitro. J Physiol 543:531-540. CrossRef Medline

Marinelli S, Di Marzo V, Berretta N, Matias I, Maccarrone M, Bernardi G, Mercuri NB (2003) Presynaptic facilitation of glutamatergic synapses to dopaminergic neurons of the rat substantia nigra by endogenous stimulation of vanilloid receptors. J Neurosci 23:3136-3144. Medline

Marsch R, Foeller E, Rammes G, Bunck M, Kössl M, Holsboer F, Zieglgäns- berger W, Landgraf R, Lutz B, Wotjak CT (2007) Reduced anxiety, conditioned fear, and hippocampal long-term potentiation in transient receptor potential vanilloid type 1 receptor-deficient mice. J Neurosci 27:832-839. CrossRef Medline

Mezey E, Tóth ZE, Cortright DN, Arzubi MK, Krause JE, Elde R, Guo A, Blumberg PM, Szallasi A (2000) Distribution of mRNA for vanilloid receptor subtype 1 (VR1), and VR1-like immunoreactivity, in the central nervous system of the rat and human. Proc Natl Acad Sci U S A 97:36553660. CrossRef Medline

Miles R, Tóth K, Gulyás AI, Hájos N, Freund TF (1996) Differences between somatic and dendritic inhibition in the hippocampus. Neuron 16:815823. CrossRef Medline

Musella A, De Chiara V, Rossi S, Prosperetti C, Bernardi G, Maccarrone M, Centonze D (2009) TRPV1 channels facilitate glutamate transmission in the striatum. Mol Cell Neurosci 40:89-97. CrossRef Medline

Musella A, De Chiara V, Rossi S, Cavasinni F, Castelli M, Cantarella C, Mataluni G, Bernardi G, Centonze D (2010) Transient receptor potential vanilloid 1 channels control acetylcholine/2-arachidonoylglicerol coupling in the striatum. Neuroscience 167:864-871. CrossRef Medline

Ohno-Shosaku T, Kano M (2014) Endocannabinoid-mediated retrograde modulation of synaptic transmission. Curr Opin Neurobiol 29C:1-8. CrossRef Medline

Puente N, Cui Y, Lassalle O, Lafourcade M, Georges F, Venance L, Grandes P, Manzoni OJ (2011) Polymodal activation of the endocannabinoid system in the extended amygdala. Nat Neurosci 14:1542-1547. CrossRef Medline

Puente N, Reguero L, Elezgarai I, Canduela MJ, Mendizabal-Zubiaga J, Ramos-Uriarte A, Fernandez-Espejo E, Grandes P (2014) The transient receptor potential vanilloid-1 is localized at excitatory synapses in the mouse dentate gyrus. Brain Struct Funct. Advance online publication. doi:10.1007/s00429-014-0711-2. CrossRef

Roberts JC, Davis JB, Benham CD (2004) [3H]Resiniferatoxin autoradiography in the CNS of wild-type and TRPV1 null mice defines TRPV1 (VR-1) protein distribution. Brain Res 995:176-183. CrossRef Medline

Rodenas-Ruano A, Chávez AE, Cossio MJ, Castillo PE, Zukin RS (2012) REST-dependent epigenetic remodeling promotes the developmental switch in synaptic NMDA receptors. Nat Neurosci 15:1382-1390. CrossRef Medline

Ross RA (2003) Anandamide and vanilloid TRPV1 receptors. Br J Pharmacol 140:790-801. CrossRef Medline

Sasamura T, Sasaki M, Tohda C, Kuraishi Y (1998) Existence of capsaicinsensitive glutamatergic terminals in rat hypothalamus. Neuroreport 9:2045-2048. CrossRef Medline

Terzian AL, dos Reis DG, Guimarães FS, Corrêa FM, Resstel LB (2014) Medial prefrontal cortex transient receptor potential vanilloid type 1 (TRPV1) in the expression of contextual fear conditioning in Wistar rats. Psychopharmacology 231:149-157. CrossRef Medline

Tóth A, Boczán J, Kedei N, Lizanecz E, Bagi Z, Papp Z, Edes I, Csiba L, Blumberg PM (2005) Expression and distribution of vanilloid receptor 1 (TRPV1) in the adult rat brain. Brain Res Mol Brain Res 135:162-168. CrossRef Medline

Ventura A, Meissner A, Dillon CP, McManus M, Sharp PA, Van Parijs L, Jaenisch R, Jacks T (2004) Cre-lox-regulated conditional RNA interference from transgenes. Proc Natl Acad Sci U S A 101:10380-10385. CrossRef Medline

Wu ZZ, Chen SR, Pan HL (2005) Transient receptor potential vanilloid type 1 activation down-regulates voltage-gated calcium channels through calcium-dependent calcineurin in sensory neurons. J Biol Chem 280: 18142-18151. CrossRef Medline

Xing J, Li J (2007) TRPV1 receptor mediates glutamatergic synaptic input to dorsolateral periaqueductal gray (dl-PAG) neurons. J Neurophysiol 97: 503-511. CrossRef Medline

Yang K, Kumamoto E, Furue H, Yoshimura M (1998) Capsaicin facilitates excitatory but not inhibitory synaptic transmission in substantia gelatinosa of the rat spinal cord. Neurosci Lett 255:135-138. CrossRef Medline

Zhou HY, Zhang HM, Chen SR, Pan HL (2007) Increased nociceptive input rapidly modulates spinal GABAergic transmission through endogenously released glutamate. J Neurophysiol 97:871-882. CrossRef Medline 